\title{
Dnmt3a in Sim1 Neurons Is Necessary for Normal Energy Homeostasis
}

\author{
Daisuke Kohno, ${ }^{1,3,4}$ Syann Lee, ${ }^{1}$ Matthew J. Harper, ${ }^{1,2}$ Ki Woo Kim, ${ }^{1,5}$ ๑Hideyuki Sone, ${ }^{1,6}$ Tsutomu Sasaki, ${ }^{4}$ \\ Tadahiro Kitamura, ${ }^{4}$ Guoping Fan, ${ }^{7}$ and Joel K. Elmquist ${ }^{1}$ \\ ${ }^{1}$ Division of Hypothalamic Research, Departments of Internal Medicine and Pharmacology, and 2Department of Neuroscience, University of Texas \\ Southwestern Medical Center, Dallas, Texas 75390, ${ }^{3}$ Advanced Scientific Research Leaders Development Unit and ${ }^{4}$ Metabolic Signal Research Center, \\ Institute for Molecular and Cellular Regulation, Gunma University, Maebashi, 371-8512 Japan, ${ }^{5}$ Departments of Pharmacology and Global Medical Science, \\ Institute of Lifestyle Medicine, and Nuclear Receptor Research Consortium, Yonsei University Wonju College of Medicine, Wonju, 220-701, Republic of \\ Korea, ${ }^{6}$ Department of Health and Nutrition, Faculty of Human Life Studies, University of Niigata Prefecture, Higashi-ku, Niigata, 950-8680, Japan, and \\ ${ }^{7}$ Department of Human Genetics, David Geffen School of Medicine, University of California Los Angeles, Los Angeles, California 90095
}

Obesity rates continue to rise throughout the world. Recent evidence has suggested that environmental factors contribute to altered energy balance regulation. However, the role of epigenetic modifications to the central control of energy homeostasis remains unknown. To investigate the role of DNA methylation in the regulation of energy balance, we investigated the role of the de novo DNA methyltransferase, Dnmt3a, in Single-minded 1 (Sim1) cells, including neurons in the paraventricular nucleus of the hypothalamus (PVH). Dnmt3a expression levels were decreased in the PVH of high-fat-fed mice. Mice lacking Dnmt3a specifically in the Sim1 neurons, which are expressed in the forebrain, including PVH, became obese with increased amounts of abdominal and subcutaneous fat. The mice were also found to have hyperphagia, decreased energy expenditure, and glucose intolerance with increased serum insulin and leptin. Furthermore, these mice developed hyper-LDL cholesterolemia when fed a high-fat diet. Gene expression profiling and DNA methylation analysis revealed that the expression of tyrosine hydroxylase and galanin were highly upregulated in the PVH of Sim1-specific Dnmt3a deletion mice. DNA methylation levels of the tyrosine hydroxylase promoter were decreased in the PVH of the deletion mice. These results suggest that Dnmt3a in the PVH is necessary for the normal control of body weight and energy homeostasis and that tyrosine hydroxylase is a putative target of Dnmt3a in the PVH. These results provide evidence for a role for Dnmt3a in the PVH to link environmental conditions to altered energy homeostasis.

Key words: DNA methylation; Dnmt3a; epigenetics; feeding; hypothalamus; obesity

\section{Introduction}

Global obesity rates are increasing rapidly; however, the factors underlying this phenomenon are not fully understood. Although genetic and environmental factors are both important for maintaining energy homeostasis, the relative extent of their contributions is still to be established. Despite the identification of single gene mutations in some cases of severe obesity (Montague et al.,

Received April 1, 2014; revised Sept. 29, 2014; accepted 0ct. 2, 2014.

Author contributions: D.K., S.L., and J.K.E. designed research; D.K., S.L., M.J.H., K.W.K., H.S., and T.S. performed research; G.F. contributed unpublished reagents/analytic tools; D.K. and T.K. analyzed data; D.K., S.L., and J.K.E. wrote the paper.

This work was supported by National Institutes of Health (NIH) Grants R01DK088423, RL1DK081185, and R37DK053301 (J.K.E.), JSPS KAKENHI Grant 25126724 and 25870666 (D.K.), the Mishima Kaiun Memorial Foundation (D.K.), and National Research Foundation of Korea Grant NRF-2013R1A1A1007693 (K.W.K.). We thank the Mouse Metabolic Phenotyping Core and Genomics and the Microarray Core at UT Southwestern Medical Center at Dallas (supported by NIH Grants P01 DK088761, PL1 DK081182, and UL1RR024923). We thank A. Ali, D. Lauzon, M. Kim, L. Cao, and C. E. Lee for technical assistance and members in the Division of Hypothalamic Research, University of Texas for helpful comments.

The authors declare no competing financial interests.

Correspondence should be addressed to either of the following: Dr. Joel K. Elmquist, 5323 Harry Hines Boulevard Dallas, TX 75390-8591, E-mail: joel.elmquist@UTSouthwestern.edu; or Dr. Daisuke Kohno, 3-39-22 Showa-machi, Maebashi, Gunma 371-8511, Japan. E-mail: daisuke.kohno@gunma-u.ac.jp.

DOI:10.1523/JNEUROSCI.1316-14.2014

Copyright $\odot 2014$ the authors $\quad 0270-6474 / 14 / 3415288-09 \$ 15.00 / 0$
1997; Clément et al., 1998; Krude et al., 1998; Yeo et al., 1998), the frequency of monogenic obesity in the general population is estimated to be low (Vaisse et al., 2000; Hinney et al., 2010; Yeo and Heisler, 2012).

How environmental factors cause long-term changes in metabolism remains unclear, but emerging evidence has suggested the importance of epigenetic gene regulation in the development of obesity. The epigenetic status of a gene can be altered in response to environmental changes and affects gene expression (Jirtle and Skinner, 2007; Feil and Fraga, 2011). One form of epigenetic modification involves the addition of a methyl group to DNA cytosine residues (Law and Jacobsen, 2010). Several groups have described developmental programming models in which environmental factors cause long-term physiological changes that increase the risk of obesity and metabolic disease later in life (Ravelli et al., 1976; Barker and Osmond, 1986; Yura et al., 2005). Importantly, de novo DNA methylation actively occurs under the influence of extrinsic factors during development (Waterland and Jirtle, 2003; Jirtle and Skinner, 2007; Feil and Fraga, 2011), suggesting that methylation is critical for proper growth. Consistent with this, DNA methylation has been implicated in growth and development because the inhibition of the de novo 
C57BL/6

A
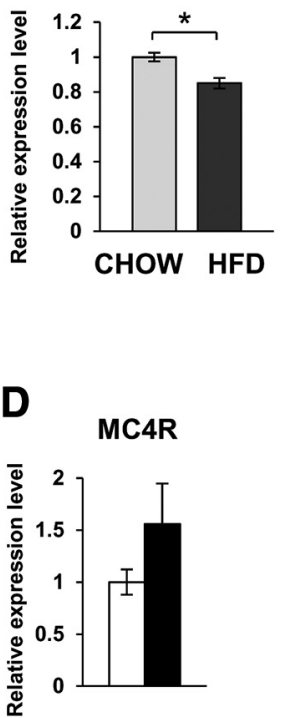

$\square$ DNMT3alox/lox

- DNMT3a $a^{\text {lox/lox/Sim1-Cre }}$

B

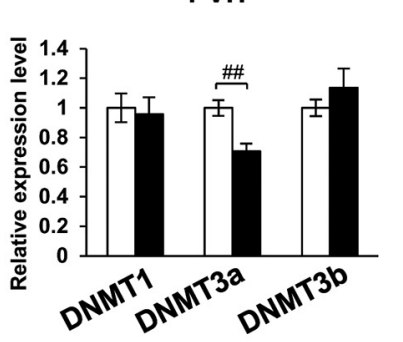

C

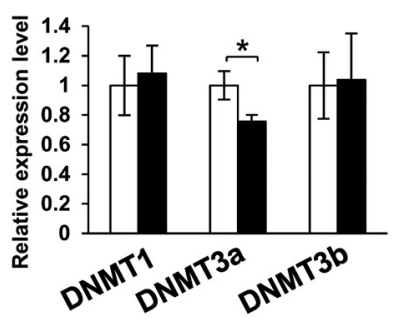

DNA methyltransferase, Dnmt3, in honeybee larva or the mutation of Dnmt3a in human leads to overgrowth or overgrowth syndrome (Kucharski et al., 2008; Tatton-Brown et al., 2014). These findings suggest a role for DNA methylation in the regulation of energy homeostasis.

The hypothalamus plays a pivotal role in the control of body weight. Specifically, the feeding effects of the melanocortin pathway are mediated through melanocortin 4 receptor (MC4R) in Sim1 neurons within the paraventricular nucleus of the hypothalamus (PVH; Balthasar et al., 2005). In addition, PVH neurons express several hormones related to feeding and metabolic regulation, including oxytocin, vasopressin, corticotropin-releasing hormone $(\mathrm{CRH})$, thyrotropin-releasing hormone neurons, and galanin. However, the extent of the contribution of each hormone to energy homeostasis is not fully understood. Previous reports have shown that the PVH is able to respond to external signals, such as stress, to maintain homeostasis (Herman et al., 2003). For instance, earlylife stressors invoke changes in the DNA methylation of the vasopressin gene within the PVH (Murgatroyd et al., 2009). Furthermore, the expression of methyl-cytosine binding protein 2 (MeCP2), a protein with a methyl-CpG-binding domain, in the Sim1 neurons is associated with stressrelated behavior and is required to regulate energy homeostasis (Fyffe et al., 2008). Considering these facts, we hypothesize that the PVH plays an important role in the epigenetic regulation of obesity.

To examine the role of DNA methylation in the hypothalamic control of body weight, we investigated the role of Dnmt3a in PVH neurons.

\section{Materials and Methods}

Animal care. All mouse care and experimental procedures were approved by the University of Texas Southwestern and Gunma University Institutional Animal Care and Use Committee. Mice were kept at room temperature (22$24^{\circ} \mathrm{C}$ ) with a $12 \mathrm{~h}$ light/dark cycle (lights on at 6:00 A.M.). Regular chow (4\% fat diet; 7001; Harlan Laboratories) or a high-fat diet (HFD; 42\% fat diet; TD.88137; Harlan Laboratories) and water were provided ad libitum. For the HFD study in Fig. 5, regular chow or HFD was provided from 4 to 10 weeks of age. All mice had been backcrossed on the C57BL/6 background for six or more generations. To generate the Sim1-Cre-specific Dnmt3a deletion (Dnmt3a $a^{\text {lox/lox}} /$ Sim 1-Cre) mice, female mice homozygous for the floxed Dnmt3a allele (Kaneda et al., 2004; Dodge et al., 2005) were crossed with male mice homozygous for the floxed Dnmt3a allele and heterozygous for the Sim1-Cre transgene (Balthasar et al., 2005).

Figure 2. Development of obesity in Sim1-Cre-specific Dnmt3a deletion mice. $\boldsymbol{A}$, Dnmt3a ${ }^{\text {lox/lox }}$ mouse (left) and Dnmt3a ${ }^{\text {lox/lox } / ~}$ Sim1-Cre mouse (right) at 22 weeks of age. Weekly body weight of male $(n=4-13)(\boldsymbol{B})$ and female $(n=9-16)$ (C) mice. D, Body lengths of 23-week-old male $(n=6)$ and female $(n=10)$ mice. $\boldsymbol{E}$, Left, Representative CT-scan image of a Dnmt3a ${ }^{\text {lox/lox }}$ mouse (left) and a Dnmt3a ${ }^{\text {lox/lox} / S i m 1-C r e ~ m o u s e ~(r i g h t) . ~ G r e e n, ~ M u s c l e ; ~ r e d, ~ f a t . ~ R i g h t, ~ T h e ~ v o l u m e s ~ o f ~ v i s c e r a l ~ a n d ~ s u b c u t a n e o u s ~ f a t s ~ o f ~}$ 23-week-old male mice $(n=4)$. $\boldsymbol{F}$, Fat pad weight of 27-week-old male mice $(n=4)$. $\boldsymbol{G}$, Epididymal fat (top) and liver (bottom) of 24-week-old Dnmt3a lox/lox and Dnmt3a ${ }^{\text {lox/lox} / S i m 1-C r e ~ m a l e ~ m i c e ~(h e m a t o x y l i n ~ a n d ~ e o s i n ~ s t a i n i n g) . ~ S c a l e ~ b a r s, ~} 100 \mu m$. Sub, Subcutaneous fat; Peri, perirenal fat; Mes, mesenteric fat; Epi, epididymal fat; Vis, visceral fat. ${ }^{*} p<0.05,{ }^{\#} p<0.005,{ }^{\# \#} p<$ 0.001 . 
Body weight, length, composition, and fat distribution. Body weight was measured weekly in group-housed mice. Nose-to-anus body length was measured by manually immobilizing and gently extending the mice to their full length. Fat mass and lean mass were assessed by nuclear magnetic resonance (NMR) spectroscopy using an NMR spectrometer (EchoMRI-100; EchoMedical Systems). The volumes of visceral fat and subcutaneous fat were assessed using the eXplore Locus micro-CT scanner (GE Healthcare), as described previously (Xu et al., 2008). Fat pad weight was measured from dissected tissues.

Food intake, energy expenditure, and locomotor activity. Energy expenditure and locomotor activity were measured from 11-week-old male mice. Male mice were individually housed for $3 \mathrm{~d}$ before measurement of food intake. Energy expenditure was measured with the Oxymax apparatus (Columbus Instruments). Mice were monitored in the metabolic chambers over a $3 \mathrm{~d}$ period, and the data from the final day were analyzed. Oxygen consumptions were calculated by dividing lean body weights, which were measured by a CT scanner (LaTheta; Hitachi Aloka Medical). Locomotor activity in the metabolic chamber was measured with an infrared light beam detection system (ACTIMO-100; Shinfactory). The total number of beam breaks in the $x$ - and $y$-axes every 18 min was counted.

Glucose and insulin tolerance tests. For the glucose tolerance test (GTT), mice were fasted overnight (7 P.M. to 10:00 A.M.), and then 2 $\mathrm{g} / \mathrm{kg}$ glucose was administered intraperitoneally. For the insulin tolerance test (ITT), mice were first fasted for $3 \mathrm{~h}$ (11:00 A.M. to 2:00 P.M.), and then $1 \mathrm{U} / \mathrm{kg}$ insulin (Eli Lilly) was administered intraperitoneally. Tail vein blood was assayed for glucose concentration measurement using a One Touch Ultra Blood Glucose Meter (Lifescan). The area under the curve (AUC) was calculated by the trapezoidal method.

Analysis of blood samples. Food was removed from the home cage for $3 \mathrm{~h}$, and blood was collected from the tail vein for insulin, leptin, free fatty acid, triglyceride, and total cholesterol assays or after decapitation for lipoprotein measures. Insulin and leptin levels were measured using an insulin ELISA kit (catalog \#90080; Crystal Chem) and a leptin ELISA kit (catalog \#90030; Crystal Chem), respectively, according to the instructions of the manufacturer. The serum levels of free fatty acids, triglycerides, and total cholesterol were measured by Vitros 250 (Ortho-Clinical Diagnostics). For the measurement of plasma lipoprotein levels, plasma was separated with a Superose $610 / 300$ GL gel filtration column and then quantitated by the Metabolic Phenotyping Core at the University of Texas Southwestern Medical Center.

Dissection of nuclei. Mice were anesthetized with chloral hydrate (500 $\mathrm{mg} / \mathrm{kg}$ ). Coronal slices between bregma, at -0.58 and $-1.22 \mathrm{~mm}$ and -0.58 and $-2.80 \mathrm{~mm}$ were made for the PVH and amygdala respectively, and each nucleus was microdissected with a scalpel.

Microarray and quantitative PCR analysis of RNA. Total RNA was extracted from the dissected hypothalamic nuclei of 6-week-old males with TRIzol reagent (Invitrogen) and phenol/chloroform. For the microarray, RNA samples of PVH from five mice were pooled for each
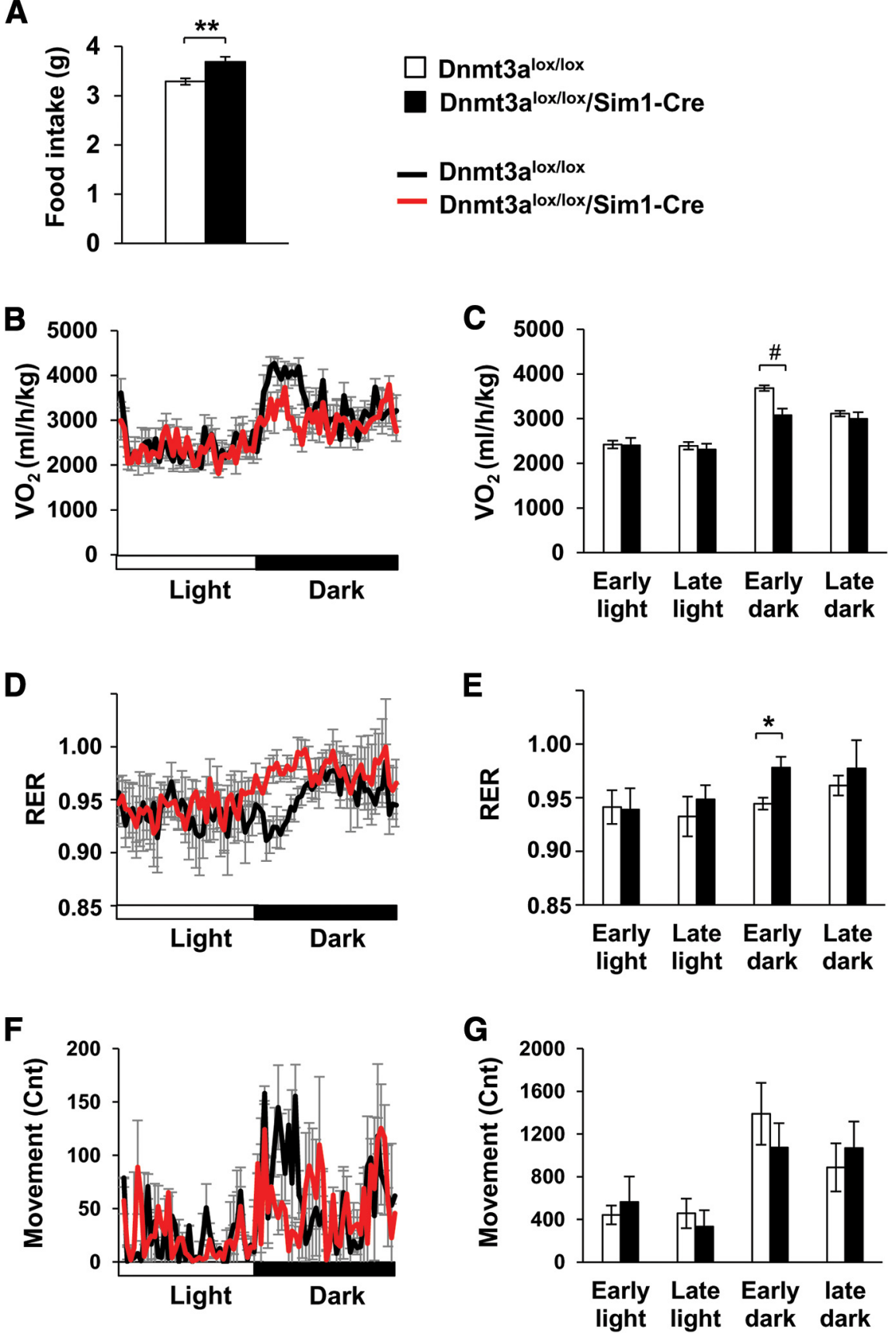

Figure 3. Food intake, energy consumption, and locomotor activity. $\boldsymbol{A}$, Daily food intake of 11-week-old $(n=5)$ male mice 0xygen consumption of 11-week-old male mice $(n=5)(\boldsymbol{B})$ and average oxygen consumption during $6 \mathrm{~h}(\boldsymbol{C})$. RER of 11-week-old male mice $(n=5)(\boldsymbol{D})$ and average RER during $6 \mathrm{~h}(\boldsymbol{E})$. Locomotor activity of 11-week-old male mice $(n=5)(\boldsymbol{F})$ and total number of movements during $6 \mathrm{~h}(\boldsymbol{G}) .{ }^{*} p<0.05,{ }^{* *} p<0.01,{ }^{\#} p<0.005$.

group, and three groups per genotype were prepared. RNA quality and concentration were confirmed using the Illumina Bioanalyzer Bioanalyzer system (Illumina). Samples were hybridized to the Mouse WG-6 v2.0 expression BeadChip (Illumina) at the University of Texas Southwestern Genomics and Microarray Core. Normalization with statistical analysis was performed with GeneSpring GX (Agilent Technologies). Expression results were deposited at the Gene Expression Omnibus (National Center for Biotechnology Information accession number GSE42304). For real-time qPCR analysis, RNA samples were treated with DNase I (Roche), and then reverse transcription was performed using the High Capacity cDNA Reverse Transcription kits (Applied Biosystems). TaqMan assays were performed using primers and probes for Dnmt1 (Mm01151063_m1), Dnmt3a (Mm00432881_m1), Dnmt3b 

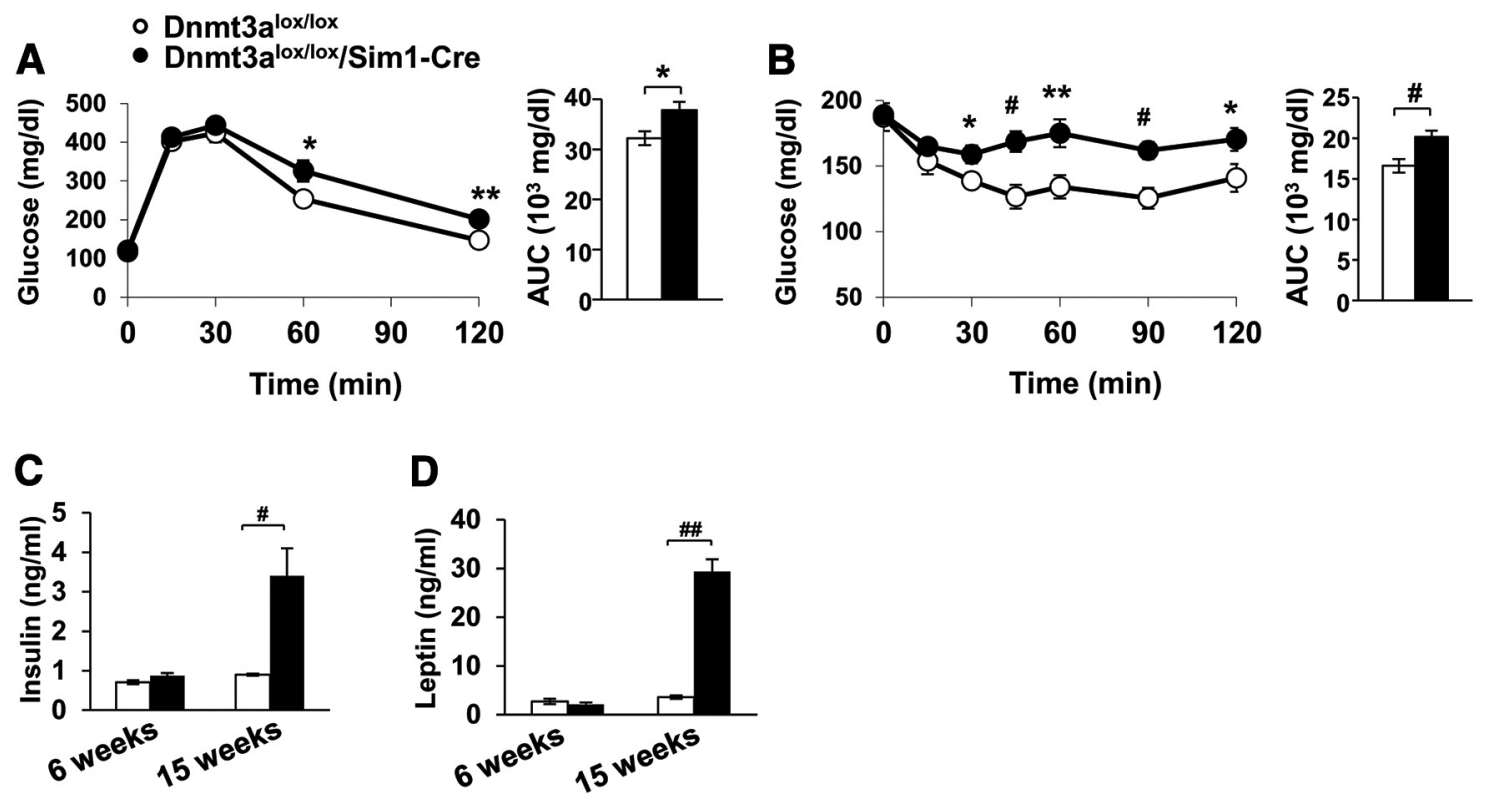

Figure 4. Glucose homeostasis and hormone levels. A, Blood glucose levels and AUC during GTT of 12-week-old male mice $(n=12) . B$, Blood glucose levels and AUC during ITT of 14 -week-old male mice $(n=11)$. Serum insulin $(\boldsymbol{C})$ and leptin (D) levels of 6 - and 15 -week-old male mice. ${ }^{*} p<0.05,{ }^{* *} p<0.01,{ }^{\#} p<0.005,{ }^{\# \#} p<0.001$.

(Mm01240113_m1), tyrosine hydroxylase (TH; Mm00447546_m1), galanin (Mm00439056_m1), MC4R (Mm00457483_s1), BDNF (Mm04230607_s1), CRH (Mm01293920_s1), and 18S (Hs99999901_s1) from Applied Biosystems. The ddCT method was used to express mRNA levels in arbitrary units.

Bisulfite sequencing. Genomic DNA was isolated from dissected PVH of 6-week-old males by proteinase $\mathrm{K}$ digestion, phenol:chloroform extraction, and ethanol precipitation. Genomic DNA was treated with sodium bisulfite and purified using the EZ DNA methylation kit (Zymo Research). PCR amplification was performed with Zymo TaqDNA polymerase (Zymo Research) and outer primers for TH gene (forward, 5'-TGTTTTGGTTTGATTAGAGAGTTTTAGA-3'; reverse, $5^{\prime}$-CCCCTAAATAACAACATATCATCCT- $\left.3^{\prime}\right)$ and then inner primers for the TH gene (forward, 5'-TTGGTTTGATTAGAGAGTTTTAGATGTT-3'; reverse, 5'-AATTCTATCTCCACAACCCTTACC-3') and for galanin gene (forward, $5^{\prime}$-TATATTAGTTTAGTTTTGGGAAGGAAA GTAA- ${ }^{\prime}$; reverse, $5^{\prime}$-AACTAATCAATACAAAATCAAAACTCTCTC$\left.3^{\prime}\right)$. The PCR products were cloned using the TOPO TA cloning kit (Invitrogen). After incubating with the Illustra TempliPhi amplification kit (GE Healthcare), products were sequenced. More than 24 clones per genotype were sequenced.

Protein analysis. Protein analysis was performed as described previously (Kim et al., 2012). PVH tissue from control or deletion mice was homogenized in lysis buffer [ $20 \mathrm{~mm}$ Tris, $5 \mathrm{~mm}$ EDTA, and 1\% NP-40 $(\mathrm{v} / \mathrm{v})$ ] containing protease inhibitors (P2714-1BTL; Sigma), then resolved by SDS-PAGE, and finally transferred to a nitrocellulose membrane. After blocking the membrane with $5 \%$ nonfat milk, proteins (TH and GAPDH) were detected using commercially available antisera [TH (catalog \#AB152) from Merck Millipore; GAPDH from Santa Cruz Biotechnology].

Histology. Mice were deeply anesthetized with chloral hydrate (500 $\mathrm{mg} / \mathrm{kg}$, i.p.) and then perfused transcardially with saline, followed by $10 \%$ Formalin (Sigma). Brains were postfixed with 10\% Formalin for $2 \mathrm{~h}$ and submerged in $20 \%$ sucrose overnight at $4^{\circ} \mathrm{C}$. Coronal sections were cut at $25 \mu \mathrm{m}$ using a freezing microtome (1:5 series). Sections were collected in PBS, $\mathrm{pH}$ 7.4, transferred to a cryoprotectant solution, and stored at $-20^{\circ} \mathrm{C}$. Sections were incubated with $3 \%$ normal donkey serum (NDS; Jackson ImmunoResearch) in PBS containing 0.05\% Triton $\mathrm{X}-100(3 \% \mathrm{NDS} / \mathrm{PBT})$ for $1 \mathrm{~h}$ and then overnight at $4^{\circ} \mathrm{C}$ with rabbit anti-TH antibody (1:500; catalog \#AB152; Merck Millipore) diluted in $3 \% \mathrm{NDS} / \mathrm{PBT}$. After washing in PBS, sections were incubated for $1 \mathrm{~h}$ with Alexa Fluor 488 donkey anti-rabbit IgG (1:400; Invitrogen) diluted in
3\% NDS. To quantify Sim1 neurons, Sim1-Cre mice were crossed with tdTomato reporter mice from the Jackson Laboratory (stock No. 007905) (Madisen et al., 2010). Neurons with Sim1-Cre-induced tdTomato fluorescence were counted, and surface areas were measured by NIH ImageJ in every section from either the right side or left side of the PVH between -0.58 and $-1.22 \mathrm{~mm}$ to bregma and the amygdala between -0.70 and $-2.80 \mathrm{~mm}$ to bregma (Paxinos and Franklin, 2001).

Statistical analysis. Data are presented as mean \pm SEM. Statistical analyses were performed using GraphPad PRISM version 6.0 (GraphPad Software). After confirming normal distribution of data, comparisons between two genotypes were made by the unpaired Student's $t$ test. Twoway ANOVA analyses were used to assess the interactions between genotypes and treatments with relevant post hoc tests. $p<0.05$ was considered statistically significant.

\section{Results}

Decreased Dnmt3a expression in HFD-induced obese mice

Environmental factors contribute to the development of obesity, including the consumption of an HFD (Surwit et al., 1988; Enriori et al., 2007). We first examined Dnmt3a expression levels in the PVH of mice fed regular chow or an HFD. Mice fed an HFD had significantly decreased Dnmt3a expression levels in the PVH (Fig. 1A), suggesting that Dnmt3a in the PVH is regulated in response to dietary intake.

\section{Generation of mice lacking Dnmt3a in Sim1 neurons}

To directly address the role of Dnmt3a in the PVH, we generated Sim1 neuron-specific Dnmt3a deletion (Dnmt3a ${ }^{\text {lox/lox}} /$ Sim1-Cre) mice by crossing floxed Dnmt3a mice (Kaneda et al., 2004; Dodge et al., 2005) with Sim1-Cre mice, which express Cre recombinase in subsets of neurons (Balthasar et al., 2005). As predicted, in the PVH and amygdala in which Sim 1 is known to be expressed, Dnmt3a mRNA expression levels were significantly decreased, whereas Dnmt1 and Dnmt3b mRNA expression levels were not altered (Fig. $1 B, C$ ). The numbers and densities of Sim 1 neurons expressing tdTomato were not different in the $\mathrm{PVH}$ and amygdala between Sim 1-Cre/tdTomato mice and Dnmt3a lox/lox/ Sim1-Cre/tdTomato mice [PVH, 852.25 \pm 86.34 neurons 
$\left(658.07 \pm 11.67\right.$ neurons $\left./ \mathrm{mm}^{2}\right)$ vs $830.75 \pm 102.32$ neurons $(661.62 \pm 26.67$ neurons $\left./ \mathrm{mm}^{2}\right), \quad n=4, p>0.05$; amygdala, $1990.75 \pm 129.05$ neurons $\left(176.91 \pm 7.86\right.$ neurons $\left./ \mathrm{mm}^{2}\right)$ vs $2006.00 \pm 145.89$ neurons (179.60 \pm 11.05 neurons $\left./ \mathrm{mm}^{2}\right), n=4, p>0.05$ ].

Development of obesity in Dnmt $3 a^{\text {lox/lox}} /$ Sim1-Cre mice

Dnmt3a $a^{\text {lox/lox }}$ and Dnmt $3 a^{\text {lox/lox}} /$ Sim1Cre mice were born at the expected genotype and sex ratios and showed normal development until $\sim 6$ weeks of age. Starting at 7 weeks of age, the body weights of both male and female Dnmt3alox/lox/ Sim1-Cre mice were significantly higher than those of the controls (Fig. $2 A-C$ ). Both male and female Dnmt3alox/lox/ Sim1-Cre mice also had significantly greater body lengths than those of controls (Fig. 2D), suggesting enhanced linear growth. Microcomputed tomography imaging showed an increase in the volumes of both visceral and subcutaneous fat depots (Fig. 2E). The weight of each dissected fat pad, including brown adipose tissue (BAT), was significantly increased in Dnmt3a ${ }^{\text {lox/lox}} /$ Sim1-Cre mice (Fig. $2 F$ ). White adipose tissue (WAT) cells were larger in Dnmt3alox/lox/Sim1-Cre mice, and their livers contained many large fatty vesicles (Fig. 2G), suggesting the accumulation of fat in WAT and the liver. These data indicate that Dnmt3a ${ }^{\text {lox/ }}$ lox/Sim1-Cre mice developed obesity with overgrowth and increased adiposity.

Food intake, energy expenditure, and locomotor activity of Dnmt3a $a^{\text {lox/lox } /}$ Sim1-Cre mice

To identify potential mechanisms underlying the obesity seen in Dnmt3a $\mathrm{a}^{\text {lox/lox}} / \mathrm{Sim} 1-$ Cre mice, we monitored food intake and energy expenditure in 11-week old chowfed mice. Daily food intake was significantly increased in Dnmt3a ${ }^{\text {lox/ }}$ lox/Sim1-Cre mice (Fig. 3A). Oxygen consumption was significantly decreased during the early dark phase (Fig. $3 B, C$ ). Furthermore, respiratory exchange rates (RERs) were significantly increased during the early dark phase (Fig. $3 D, E$ ), suggesting that fat utilization is decreased in Dnmt $3 a^{\text {lox/lox}} /$ Sim1-Cre mice. The total number of beam breaks were not significantly different between genotypes (Fig. $3 F, G$ ).

Glucose homeostasis in Dnmt3a ${ }^{\text {lox/lox}} /$ Sim1-Cre mice We next assessed glucose homeostasis in mutant mice by performing GTTs and ITTs using 12- and 14-week-old mice, respectively. Blood glucose levels of Dnmt3a ${ }^{\text {lox/lox}} /$ Sim1-Cre mice were significantly higher at 60 and $120 \mathrm{~min}$ after the initial glucose injection of the GTT (Fig. 4A). ITT results showed decreased glucose excursion in Dnmt $3 \mathrm{a}^{\text {lox/lox}} /$ Sim 1-Cre mice after insulin injection (Fig. 4B). These results suggest impairment in glucose tolerance and insulin sensitivity in Dnmt3a $\mathrm{a}^{\text {lox/lox}} / \mathrm{Sim} 1-$
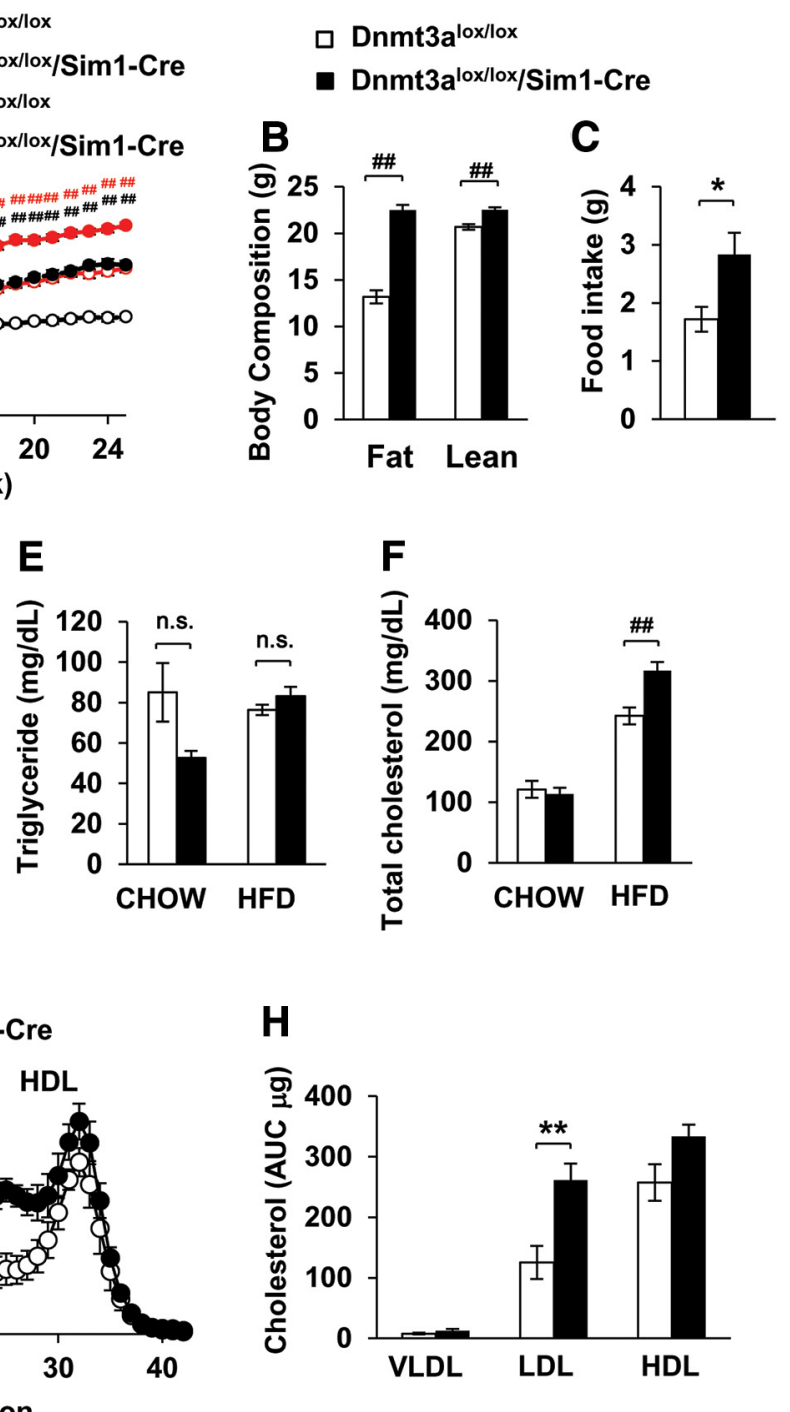

Fraction

Figure 5. Body weight and serum lipid of HFD-fed mice. A, Body weight of HFD-fed (red) $(n=8)$ and chow-fed (black, taken $(n=8)(\boldsymbol{E})$, and total cholesterol $(n=8)(\boldsymbol{F})$ of 20-week-old chow- or HFD-fed male mice. Cholesterol distribution of differen lipoproteins in the plasma of 22-week-old HFD-fed male mice $(n=4)(\boldsymbol{G})$ and its quantification based on AUC $(n=4)(\boldsymbol{H}) .{ }^{*} p<$ $0.05,{ }^{* *} p<0.01,{ }^{\# \#} p<0.001 ;$ n.S., not significant. HDL, High-density lipoprotein; VLDL, very LDL.

Cre mice, consistent with their obesity. Furthermore, serum insulin and leptin levels in Dnmt $3 \mathrm{a}^{\text {lox/lox}} /$ Sim1-Cre mice were significantly increased after the onset of obesity (Fig. 4C,D).

Effects of an HFD on Dnmt3a $a^{\text {lox/lox}} /$ Sim1-Cre mice

Exposure to HFD accelerates the onset of obesity and metabolic disease in mice (Surwit et al., 1988; Enriori et al., 2007). To investigate the effects of an HFD on Dnmt $3 \mathrm{a}^{\text {lox/lox}} /$ Sim 1-Cre mice, an HFD was given to mice at 4 weeks of age. Body weights of HFDfed Dnmt3a ${ }^{\text {lox/lox}} /$ Sim 1-Cre mice were significantly higher than both HFD-fed or chow-fed controls at 7 weeks of age and onward (Fig. 5A). The weight gain of Dnmt3a ${ }^{\text {lox/lox}} /$ Sim1-Cre mice from an HFD suggests that an HFD exacerbates the underlying deficits in energy homeostasis. Fat mass and daily food intake were markedly increased in HFD-fed Dnmt $3 \mathrm{a}^{\text {lox/lox}} /$ Sim $1-C r e$ mice compared with HFD-fed controls (Fig. $5 B, C$ ), although serum levels of free fatty acids and triglycerides were not changed compared with HFD-fed controls (Fig. $5 D, E$ ). Serum levels of total choles- 
Table 1. Upregulated genes in the PVH of Dnmt3a ${ }^{\text {lox/lox}} /$ Sim1-Cre mice

\begin{tabular}{llll}
\hline & Gene name & Ratio & $p$ \\
\hline 1 & tyrosine hydroxylase & 2.660507 & $3.96 \mathrm{E}-04$ \\
2 & peripherin & 2.6354835 & $1.82 \mathrm{E}-04$ \\
3 & BCL2-associated athanogene 3 & 2.5387166 & $2.51 \mathrm{E}-04$ \\
4 & galanin & 1.6397358 & 0.00270456 \\
5 & heat shock protein 8 & 1.636341 & 0.003290614 \\
6 & defensin $\beta$ 18 & 1.606619 & 0.007948344 \\
7 & aminopeptidase-like 1 & 1.6028643 & $6.88 \mathrm{E}-04$ \\
8 & delta-like 1 homolog (Drosophila) & 1.5616035 & 0.01880776 \\
9 & hairless & 1.5321076 & 0.047571965 \\
10 & synuclein, $\gamma$ & 1.5182372 & 0.016899046 \\
11 & parvalbumin & 1.5103999 & 0.028791681 \\
12 & MFNG 0-fucosylpeptide 3- $\beta$-N-acetylglucosami- & 1.4997038 & 0.004177414 \\
& $\quad$ nyltransferase & & \\
13 & FXYD domain-containing ion transport regulator 5 & 1.4994419 & 0.00908534 \\
14 & heat shock protein 8 & 1.4864532 & 0.002258734 \\
15 & delta-like 1 homolog (Drosophila) & 1.4723254 & 0.017169517 \\
16 & vacuolar protein sorting 39 (yeast) & 1.4647563 & 0.04716649 \\
17 & Usher syndrome 1C homolog (human) & 1.4588162 & 0.001719369 \\
18 & peptidase inhibitor 16 & 1.4144703 & 0.024257472 \\
19 & aminopeptidase-like 1 & 1.4108219 & $3.37 \mathrm{E}-05$ \\
20 & Fez family zinc finger 2 & 1.4053768 & 0.002467002 \\
\hline
\end{tabular}

Genes in which the microarray result ratio was $>1.4$ and the $p$ value was $<0.05$ are listed.

Table 2. Downregulated genes in the PVH of Dnmt3a lox/lox/Sim1-Cre mice

\begin{tabular}{llll}
\hline & Gene name & Ratio & $p$ \\
\hline 1 & somatostatin & -1.4807056 & 0.018505102 \\
2 & ceroid-lipofuscinosis, neuronal 5 & -1.4673768 & 0.00345165 \\
3 & CART prepropeptide & -1.4599158 & $5.25 \mathrm{E}-04$ \\
4 & tachykinin 1 & -1.415608 & 0.001801964 \\
5 & RNA binding motif protein 26 & -1.4033972 & 0.009544461 \\
\hline
\end{tabular}

Genes in which the microarray result ratio was $>1.4$ and the $p$ value was $<0.05$ are listed.

terol and LDL cholesterol were significantly higher in HFD-fed Dnmt $3 a^{\text {lox/lox}} /$ Sim1-Cre mice (Fig. $5 F-H$ ).

Increase of expression level and decrease of methylation level of TH gene in the PVH of Dnmt $3 \mathrm{a}^{\text {lox/lox}} / \mathrm{Sim} 1-$ Cre mice

We compared gene expression levels in the $\mathrm{PVH}$ between Dnmt3a ${ }^{\text {lox/lox }}$ mice and Dnmt3a ${ }^{\text {lox/lox }} /$ Sim 1-Cre mice by using Illumina microarray technology. Using a 1.4-fold change in expression as a cutoff, we found that 20 probes were upregulated and five probes were downregulated in the PVH of Dnmt3a $\mathrm{a}^{\text {lox/lox} /}$ Sim1-Cre mice (Tables 1, 2). Interestingly, the most upregulated gene was $\mathrm{TH}$, which is a rate-limiting enzyme in catecholamine synthesis. Galanin, an orexigenic peptide related to fat preference (Akabayashi et al., 1994), was the fourth most upregulated gene. The increased body length in Dnmt3a $\mathrm{a}^{\text {lox/lox} / S i m 1-C r e ~ m i c e ~}$ could be attributable to the decreased level of somatostatin (Table 2), which inhibits the release of growth hormone. Real-time qPCR analysis confirmed these findings, with a fivefold upregulation of TH and twofold upregulation of galanin in the PVH of Dnmt3a ${ }^{\text {lox/lox}} /$ Sim1-Cre mice (Fig. 6A). Protein levels of TH were also significantly increased in the PVH of the Dnmt $3 \mathrm{a}^{\text {lox/lox} /}$ Sim1-Cre mice (Fig. 6B).

We also performed immunohistochemical analysis and confirmed the colocalization of TH with Sim1-Cre neurons (Fig. $6 C)$. Sodium bisulfite sequencing showed that DNA methylation levels in the TH promoter region (Iwata et al., 1992; Okuse et al., 1997) were decreased in the PVH of Dnmt $3 a^{\text {lox/lox} / S i m 1-C r e ~}$ mice (Fig. 6D), whereas levels in the galanin gene promoter region (Kofler et al., 1996) were unaltered (Fig. 6E). These results suggest that the TH promoter, but not galanin, is a direct target of Dnmt3a.

\section{Discussion}

This study demonstrates that Dnmt3a levels in the PVH are altered in response to nutritional state and that Dnmt3a in the Sim 1 neurons is necessary for normal energy homeostasis. Mice lacking Dnmt3a in Sim1 neurons rapidly developed obesity, hyperphagia, glucose intolerance, and hyper-LDL cholesterolemia when fed an HFD. These mice had altered methylation and expression of the TH gene, suggesting that DNA methylation in the PVH plays an important role for the regulation of $\mathrm{TH}$.

Dnmt3a expression levels were significantly decreased in the PVH of HFD-fed mice. Consistent with our data, Dnmt3a mRNA expression is altered in WAT of obese mice (Kamei et al., 2010), suggesting a close link between Dnmt3a mRNA expression and obesity. Furthermore, Dnmt3a expression level is decreased in the liver of rats from high-fat sucrose-fed mothers during lactation, and this decrease was prevented by methyl donor supplementation during lactation (Cordero et al., 2013). Although the transcription factors controlling Dnmt3a expression are not fully understood, the mechanisms underlying Dnmt3a transcription during the development of obesity needs to be clarified. In this study, we found a small, but significant, decrease in Dnmt3a in response to an HFD. Consistent with our findings, Dnmt3a mRNA levels in the nucleus accumbens also showed a small, but significant, decrease in expression in response to external factors (LaPlant et al., 2010). Although these changes in expression are not robust, the ubiquitous expression of Dnmt3a and the fact that the brain comprises multiple cell types (including neurons and glia) makes it difficult to assess the full extent of Dnmt3a alterations.

Consistent with our current data, mice with a Sim1-specific deletion of MeCP2 also develop obesity and altered behaviors (Fyffe et al., 2008). These studies highlight the importance of DNA methylation in the PVH for the control of energy homeostasis. In both mouse models, MC4R expression levels were not changed significantly (Fig. 1D), whereas only the MeCP2 deletion mice showed downregulation of BDNF and CRH gene expression (Fyffe et al., 2008; Fig. 1E,F). In our Sim1-specific Dnmt3a deletion mice, the mRNA expression levels of TH were highly upregulated in the $\mathrm{PVH}$, and DNA methylation of the TH promoter was decreased. These results suggest that $\mathrm{TH}$ is a target of Dnmt3a in the PVH. Notably, previous findings reported that both postnatal and maternal HFD consumption increases TH gene expression and that this is accompanied by decreased DNA methylation in the hypothalamus but not in the VTA (Vucetic et al., 2010, 2012).

Hypothalamic-specific regulation of Dnmt3a activity and TH expression could be a potential mechanism behind HFD-induced obesity and developmental programming. Although it is still unknown which catecholamines are upregulated, norepinephrine is an attractive candidate. The PVH is a primary site for norepinephrine action (Leibowitz, 1978), and norepinephrine injections into the PVH induce feeding through the hypothalamic-pituitary-adrenal axis (Leibowitz et al., 1984). Furthermore, norepinephrine levels in the PVH are highest at the beginning of dark period in rats (Stanley et al., 1989). Altered expression of TH and catelcholamines, such as norepinephrine, in the PVH could be the underlying mechanism of the phase-specific reductions of energy expenditure seen in Dnmt3a lox/lox/Sim1-Cre mice. Although previous experiments have shown that corticosteroid administration and stress can induce epigenetic alterations to CRH (Elliott et al., 2010; 
Sharma et al., 2013), CRH mRNA expression levels were unchanged in our mice. This suggests that nongenomic actions on $\mathrm{CRH}$ neurons, such as neuronal activation, could be an underlying mechanism of norepinephrine regulation.

Another possibility is the upregulation of dopamine. Dopamine is critical for meal initiation and food reward (Zhou and Palmiter, 1995; Volkow et al., 2011), and dopamine action in the hypothalamus promotes food intake (Meguid et al., 2000). Interestingly, developmental programmed mice caused by maternal HFD show altered food preference accompanied with epigenetic alteration in the dopamine pathway (Vucetic et al., 2010; Grissom et al., 2014). Dnmt3a in the Sim1 neurons could be involved in the alteration of the dopamine pathway and subsequent alteration of the food reward system.

It has been shown that $\mathrm{TH}$ levels regulate BAT thermogenesis and sympathetic outflow (Shi et al., 2013). However, in our model, decreased energy expenditure and increased RER were associated with $\mathrm{PVH}$ $\mathrm{TH}$ expression. This discrepancy could be caused by heterogeneity of PVH TH neurons, which likely include both norepinephrine- and dopamine-producing neurons (Meister and Elde, 1993; Plagemann et al., 1998; Fujikawa et al., 2007; Dudas et al., 2010). TH neurons are distributed widely in and around the PVH, including the medial part and posterior part of the PVH, periventricular nucleus, and zona incerta (Ruggiero et al., 1984). The specific subpopulations of $\mathrm{PVH} \mathrm{TH}$ neurons responsible for feeding, energy expenditure, and thermogenesis need to be clarified.

Galanin expression was also upregulated in the PVH of our Sim1-specific Dnmt3a deletion mice. Similarly, galanin expression level is increased in the PVH of rats from HFD-fed dams (Chang et al., 2008). However, our methylation analysis of galanin suggested that the proximal promoter region, in which methylation is linked to galanin expression (Misawa et al., 2013), is not a direct target of Dnmt3ainduced methylation. It is possible that non-promoter regions, including the enhancer region, intergenic region, and gene body, which have also been linked to gene expression, may be altered ( $\mathrm{Wu}$ et al., 2010; Sandovici et al., 2011; Wiench et al., 2011; Aran et al., 2013). Additional studies including the non-promoter DNA methylation of galanin gene are necessary to uncover the molecular mechanisms underlying galanin upregulation.
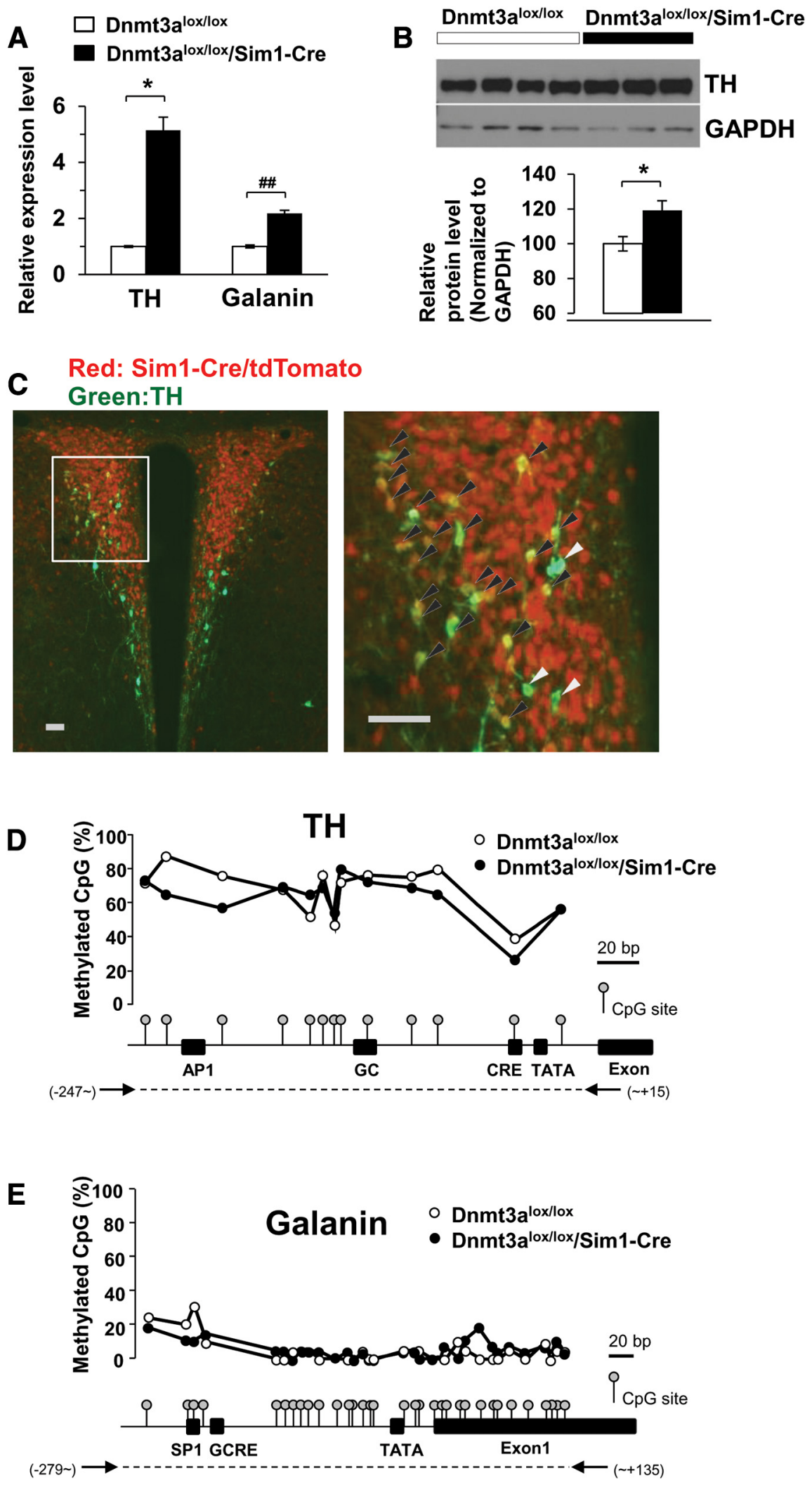

Figure 6. Analysis of TH gene in the PVH. A, qPCR analysis of mRNA expression levels of TH and galanin in the PVH (5 mice were pooled for each group, 3 groups per genotype). $\boldsymbol{B}$, TH protein levels in the PVH. $\boldsymbol{C}$, Colocalization of TH-immunoreactive neurons (green) and Sim1-Cre-specific tdTomato fluorescence (red) in the PVH. White arrowheads indicate TH-expressing neurons, and black arrowheads indicate TH and Sim1-Cre/tdTomato coexpressing neurons. Scale bar, $50 \mu \mathrm{m}$. Bisulfite sequencing of the TH gene promoter region $(\boldsymbol{D})$ and galanin gene promoter region $(\boldsymbol{E})$. AP1, AP1 binding site; $G C, G C$ box; CRE, Cre binding site; TATA, TATA box; SP1, SP1 binding site; GCRE, glucocorticoid response element. ${ }^{*} p<0.05,{ }^{\# \#} p<0.001$. 
LDL cholesterol levels were increased in Dnmt $3 \mathrm{a}^{\text {lox/lox}} /$ Sim1Cre mice fed an HFD, whereas free fatty acid and triglyceride levels were not altered. Consistent with this finding, people born with low birth weights have a trend toward increased LDL cholesterol but normal triglyceride levels (Barker et al., 1993; Barker, 1997). Because hypothalamic neuronal pathways also regulate circulating cholesterol levels (Perez-Tilve et al., 2010), it is possible that DNA methylation in the PVH could underlie these changes in LDL cholesterol. Pre-autonomic PVH neurons include a subset of PVH neurons directly innervating parasympathetic and sympathetic preganglionic neurons located in the brainstem and spinal cord, respectively (Swanson and Sawchenko, 1980; Biag et al., 2012). Studies using transsynaptic viral tracers have also established that the liver and WAT receive innervation from pre-autonomic PVH neurons in a multisynaptic manner (Bamshad et al., 1998; Bartness et al., 2010; Foster et al., 2010; Stanley et al., 2010). Pre-autonomic PVH neurons connected to these metabolic tissues may be ideally positioned to regulate glucose production, fatty acid transport, and lipolysis (Puschel, 2004; Bartness et al., 2010). These neurons may also be involved in the modulation of peripheral LDL cholesterol level.

Collectively, our findings underscore the importance of Dnmt3a in the regulation of body weight and energy homeostasis by PVH neurons. Moreover, our work suggests that epigenetic gene regulation in Sim1 neurons, mediated by Dnmt3a, on target genes such as TH may play a role in the normal control of body weight and energy homeostasis.

\section{References}

Akabayashi A, Koenig JI, Watanabe Y, Alexander JT, Leibowitz SF (1994) Galanin-containing neurons in the paraventricular nucleus: a neurochemical marker for fat ingestion and body weight gain. Proc Natl Acad Sci U S A 91:10375-10379. CrossRef Medline

Aran D, Sabato S, Hellman A (2013) DNA methylation of distal regulatory sites characterizes dysregulation of cancer genes. Genome Biol 14:R21. CrossRef Medline

Balthasar N, Dalgaard LT, Lee CE, Yu J, Funahashi H, Williams T, Ferreira M, Tang V, McGovern RA, Kenny CD, Christiansen LM, Edelstein E, Choi B, Boss O, Aschkenasi C, Zhang CY, Mountjoy K, Kishi T, Elmquist JK, Lowell BB (2005) Divergence of melanocortin pathways in the control of food intake and energy expenditure. Cell 123:493-505. CrossRef Medline

Bamshad M, Aoki VT, Adkison MG, Warren WS, Bartness TJ (1998) Central nervous system origins of the sympathetic nervous system outflow to white adipose tissue. Am J Physiol 275:R291-R299. Medline

Barker DJ (1997) Fetal nutrition and cardiovascular disease in later life. Br Med Bull 53:96-108. CrossRef Medline

Barker DJ, Osmond C (1986) Infant mortality, childhood nutrition, and ischaemic heart disease in England and Wales. Lancet 1:1077-1081. CrossRef Medline

Barker DJ, Martyn CN, Osmond C, Hales CN, Fall CH (1993) Growth in utero and serum cholesterol concentrations in adult life. BMJ 307:15241527. CrossRef Medline

Bartness TJ, Shrestha YB, Vaughan CH, Schwartz GJ, Song CK (2010) Sensory and sympathetic nervous system control of white adipose tissue lipolysis. Mol Cell Endocrinol 318:34-43. CrossRef Medline

Biag J, Huang Y, Gou L, Hintiryan H, Askarinam A, Hahn JD, Toga AW, Dong HW (2012) Cyto- and chemoarchitecture of the hypothalamic paraventricular nucleus in the C57BL/6J male mouse: a study of immunostaining and multiple fluorescent tract tracing. J Comp Neurol 520:633. CrossRef Medline

Chang GQ, Gaysinskaya V, Karatayev O, Leibowitz SF (2008) Maternal high-fat diet and fetal programming: increased proliferation of hypothalamic peptide-producing neurons that increase risk for overeating and obesity. J Neurosci 28:12107-12119. CrossRef Medline

Clément K, Vaisse C, Lahlou N, Cabrol S, Pelloux V, Cassuto D, Gourmelen $M$, Dina $C$, Chambaz J, Lacorte JM, Basdevant $A$, Bougnères $P$, Lebouc $Y$, Froguel P, Guy-Grand B (1998) A mutation in the human leptin recep- tor gene causes obesity and pituitary dysfunction. Nature 392:398-401. CrossRef Medline

Cordero P, Milagro FI, Campion J, Martinez JA (2013) Maternal methyl donors supplementation during lactation prevents the hyperhomocysteinemia induced by a high-fat-sucrose intake by dams. Int J Mol Sci 14:24422-24437. CrossRef Medline

Dodge JE, Okano M, Dick F, Tsujimoto N, Chen T, Wang S, Ueda Y, Dyson N, Li E (2005) Inactivation of Dnmt3b in mouse embryonic fibroblasts results in DNA hypomethylation, chromosomal instability, and spontaneous immortalization. J Biol Chem 280:17986-17991. CrossRef Medline

Dudas B, Baker M, Rotoli G, Grignol G, Bohn MC, Merchenthaler I (2010) Distribution and morphology of the catecholaminergic neural elements in the human hypothalamus. Neuroscience 171:187-195. CrossRef Medline

Elliott E, Ezra-Nevo G, Regev L, Neufeld-Cohen A, Chen A (2010) Resilience to social stress coincides with functional DNA methylation of the Crf gene in adult mice. Nat Neurosci 13:1351-1353. CrossRef Medline

Enriori PJ, Evans AE, Sinnayah P, Jobst EE, Tonelli-Lemos L, Billes SK, Glavas MM, Grayson BE, Perello M, Nillni EA, Grove KL, Cowley MA (2007) Diet-induced obesity causes severe but reversible leptin resistance in arcuate melanocortin neurons. Cell Metab 5:181-194. CrossRef Medline

Feil R, Fraga MF (2011) Epigenetics and the environment: emerging patterns and implications. Nat Rev Genet 13:97-109. CrossRef Medline

Foster MT, Song CK, Bartness TJ (2010) Hypothalamic paraventricular nucleus lesion involvement in the sympathetic control of lipid mobilization. Obesity (Silver Spring) 18:682-689. CrossRef

Fujikawa T, Matsumura S, Yamada H, Inoue K, Fushiki T (2007) Transforming growth factor-beta in the brain enhances fat oxidation via noradrenergic neurons in the ventromedial and paraventricular hypothalamic nucleus. Brain Res 1173:92-101. CrossRef Medline

Fyffe SL, Neul JL, Samaco RC, Chao HT, Ben-Shachar S, Moretti P, McGill BE, Goulding EH, Sullivan E, Tecott LH, Zoghbi HY (2008) Deletion of Mecp2 in Sim1-expressing neurons reveals a critical role for MeCP2 in feeding behavior, aggression, and the response to stress. Neuron 59:947958. CrossRef Medline

Grissom N, Bowman N, Reyes TM (2014) Epigenetic programming of reward function in offspring: a role for maternal diet. Mammalian Genome 25:41-48. CrossRef Medline

Herman JP, Figueiredo H, Mueller NK, Ulrich-Lai Y, Ostrander MM, Choi DC, Cullinan WE (2003) Central mechanisms of stress integration: hierarchical circuitry controlling hypothalamo-pituitary-adrenocortical responsiveness. Front Neuroendocrinol 24:151-180. CrossRef Medline

Hinney A, Vogel CI, Hebebrand J (2010) From monogenic to polygenic obesity: recent advances. Eur Child Adolesc Psychiatry 19:297-310. CrossRef Medline

Iwata N, Kobayashi K, Sasaoka T, Hidaka H, Nagatsu T (1992) Structure of the mouse tyrosine hydroxylase gene. Biochem Biophys Res Commun 182:348-354. CrossRef Medline

Jirtle RL, Skinner MK (2007) Environmental epigenomics and disease susceptibility. Nat Rev Genet 8:253-262. CrossRef Medline

Kamei Y, Suganami T, Ehara T, Kanai S, Hayashi K, Yamamoto Y, Miura S, Ezaki O, Okano M, Ogawa Y (2010) Increased expression of DNA methyltransferase $3 \mathrm{a}$ in obese adipose tissue: studies with transgenic mice. Obesity (Silver Spring) 18:314-321. CrossRef Medline

Kaneda M, Okano M, Hata K, Sado T, Tsujimoto N, Li E, Sasaki H (2004) Essential role for de novo DNA methyltransferase Dnmt3a in paternal and maternal imprinting. Nature 429:900-903. CrossRef Medline

Kim KW, Donato J Jr, Berglund ED, Choi YH, Kohno D, Elias CF, Depinho RA, Elmquist JK (2012) FOXO1 in the ventromedial hypothalamus regulates energy balance. J Clin Invest 122:2578-2589. CrossRef Medline

Kofler B, Liu ML, Jacoby AS, Shine J, Iismaa TP (1996) Molecular cloning and characterisation of the mouse preprogalanin gene. Gene 182:71-75. CrossRef Medline

Krude H, Biebermann H, Luck W, Horn R, Brabant G, Grüters A (1998) Severe early-onset obesity, adrenal insufficiency and red hair pigmentation caused by POMC mutations in humans. Nat Genet 19:155-157. CrossRef Medline

Kucharski R, Maleszka J, Foret S, Maleszka R (2008) Nutritional control of reproductive status in honeybees via DNA methylation. Science 319: 1827-1830. CrossRef Medline

LaPlant Q, Vialou V, Covington HE 3rd, Dumitriu D, Feng J, Warren BL, Maze I, Dietz DM, Watts EL, Iñiguez SD, Koo JW, Mouzon E, Renthal W, 
Hollis F, Wang H, Noonan MA, Ren Y, Eisch AJ, Bolaños CA, Kabbaj M, et al. (2010) Dnmt3a regulates emotional behavior and spine plasticity in the nucleus accumbens. Nat Neurosci 13:1137-1143. CrossRef Medline

Law JA, Jacobsen SE (2010) Establishing, maintaining and modifying DNA methylation patterns in plants and animals. Nat Rev Genet 11:204-220. CrossRef Medline

Leibowitz SF (1978) Paraventricular nucleus: a primary site mediating adrenergic stimulation of feeding and drinking. Pharmacol Biochem Behav 8:163-175. CrossRef Medline

Leibowitz SF, Roland CR, Hor L, Squillari V (1984) Noradrenergic feeding elicited via the paraventricular nucleus is dependent upon circulating corticosterone. Physiol Behav 32:857-864. CrossRef Medline

Madisen L, Zwingman TA, Sunkin SM, Oh SW, Zariwala HA, Gu H, Ng LL, Palmiter RD, Hawrylycz MJ, Jones AR, Lein ES, Zeng H (2010) A robust and high-throughput Cre reporting and characterization system for the whole mouse brain. Nat Neurosci 13:133-140. CrossRef Medline

Meguid MM, Fetissov SO, Varma M, Sato T, Zhang L, Laviano A, RossiFanelli F (2000) Hypothalamic dopamine and serotonin in the regulation of food intake. Nutrition 16:843-857. CrossRef Medline

Meister B, Elde R (1993) Dopamine transporter mRNA in neurons of the rat hypothalamus. Neuroendocrinology 58:388-395. CrossRef Medline

Misawa K, Kanazawa T, Misawa Y, Uehara T, Imai A, Takahashi G, Takebayashi S, Cole A, Carey TE, Mineta H (2013) Galanin has tumor suppressor activity and is frequently inactivated by aberrant promoter methylation in head and neck cancer. Transl Oncol 6:338-346. CrossRef Medline

Montague CT, Farooqi IS, Whitehead JP, Soos MA, Rau H, Wareham NJ, Sewter CP, Digby JE, Mohammed SN, Hurst JA, Cheetham CH, Earley AR, Barnett AH, Prins JB, O'Rahilly S (1997) Congenital leptin deficiency is associated with severe early-onset obesity in humans. Nature 387:903-908. CrossRef Medline

Murgatroyd C, Patchev AV, Wu Y, Micale V, Bockmühl Y, Fischer D, Holsboer F, Wotjak CT, Almeida OF, Spengler D (2009) Dynamic DNA methylation programs persistent adverse effects of early-life stress. Nat Neurosci 12:1559-1566. CrossRef Medline

Okuse K, Matsuoka I, Kurihara K (1997) Tissue-specific methylation occurs in the essential promoter element of the tyrosine hydroxylase gene. Brain Res Mol Brain Res 46:197-207. CrossRef Medline

Paxinos G, Franklin KBJ (2001) The mouse brain in stereotaxic coordinates, Ed 2. San Diego: Academic.

Perez-Tilve D, Hofmann SM, Basford J, Nogueiras R, Pfluger PT, Patterson JT, Grant E, Wilson-Perez HE, Granholm NA, Arnold M, Trevaskis JL, Butler AA, Davidson WS, Woods SC, Benoit SC, Sleeman MW, DiMarchi RD, Hui DY, Tschöp MH (2010) Melanocortin signaling in the CNS directly regulates circulating cholesterol. Nat Neurosci 13:877-882. CrossRef Medline

Plagemann A, Harder T, Lindner R, Melchior K, Rake A, Rittel F, Rohde W, Dörner G (1998) Alterations of hypothalamic catecholamines in the newborn offspring of gestational diabetic mother rats. Brain Res Dev Brain Res 109:201-209. CrossRef Medline

Püschel GP (2004) Control of hepatocyte metabolism by sympathetic and parasympathetic hepatic nerves. Anat Rec A Discov Mol Cell Evol Biol 280:854-867. Medline

Ravelli GP, Stein ZA, Susser MW (1976) Obesity in young men after famine exposure in utero and early infancy. N Eng J Med 295:349-353. CrossRef Medline

Ruggiero DA, Baker H, Joh TH, Reis DJ (1984) Distribution of catecholamine neurons in the hypothalamus and preoptic region of mouse. J Comp Neurol 223:556-582. CrossRef Medline

Sandovici I, Smith NH, Nitert MD, Ackers-Johnson M, Uribe-Lewis S, Ito Y, Jones RH, Marquez VE, Cairns W, Tadayyon M, O’Neill LP, Murrell A, Ling C, Constância M, Ozanne SE (2011) Maternal diet and aging alter the epigenetic control of a promoter-enhancer interaction at the Hnf4a gene in rat pancreatic islets. Proc Natl Acad Sci U S A 108:5449-5454. CrossRef Medline

Sharma D, Bhave S, Gregg E, Uht R (2013) Dexamethasone induces a puta- tive repressor complex and chromatin modifications in the CRH promoter. Mol Endocrinol 27:1142-1152. CrossRef Medline

Shi YC, Lau J, Lin Z, Zhang H, Zhai L, Sperk G, Heilbronn R, Mietzsch M, Weger S, Huang XF, Enriquez RF, Baldock PA, Zhang L, Sainsbury A, Herzog H, Lin S (2013) Arcuate NPY controls sympathetic output and BAT function via a relay of tyrosine hydroxylase neurons in the PVN. Cell Metab 17:236-248. CrossRef Medline

Stanley BG, Schwartz DH, Hernandez L, Hoebel BG, Leibowitz SF (1989) Patterns of extracellular norepinephrine in the paraventricular hypothalamus: relationship to circadian rhythm and deprivation-induced eating behavior. Life Sci 45:275-282. Medline

Stanley S, Pinto S, Segal J, Pérez CA, Viale A, DeFalco J, Cai X, Heisler LK, Friedman JM (2010) Identification of neuronal subpopulations that project from hypothalamus to both liver and adipose tissue polysynaptically. Proc Natl Acad Sci U S A 107:7024-7029. CrossRef Medline

Surwit RS, Kuhn CM, Cochrane C, McCubbin JA, Feinglos MN (1988) Diet-induced type II diabetes in C57BL/6J mice. Diabetes 37:1163-1167. CrossRef Medline

Swanson LW, Sawchenko PE (1980) Paraventricular nucleus: a site for the integration of neuroendocrine and autonomic mechanisms. Neuroendocrinology 31:410-417. CrossRef Medline

Tatton-Brown K, Seal S, Ruark E, Harmer J, Ramsay E, Del Vecchio Duarte S, Zachariou A, Hanks S, O’Brien E, Aksglaede L, Baralle D, Dabir T, Gener B, Goudie D, Homfray T, Kumar A, Pilz DT, Selicorni A, Temple IK, Van Maldergem L, et al. (2014) Mutations in the DNA methyltransferase gene DNMT3A cause an overgrowth syndrome with intellectual disability. Nat Genet 46:385-388. CrossRef Medline

Vaisse C, Clement K, Durand E, Hercberg S, Guy-Grand B, Froguel P (2000) Melanocortin-4 receptor mutations are a frequent and heterogeneous cause of morbid obesity. J Clin Invest 106:253-262. CrossRef Medline

Volkow ND, Wang GJ, Baler RD (2011) Reward, dopamine and the control of food intake: implications for obesity. Trends Cogn Sci 15:37-46. CrossRef Medline

Vucetic Z, Kimmel J, Totoki K, Hollenbeck E, Reyes TM (2010) Maternal high-fat diet alters methylation and gene expression of dopamine and opioid-related genes. Endocrinology 151:4756-4764. CrossRef Medline

Vucetic Z, Carlin JL, Totoki K, Reyes TM (2012) Epigenetic dysregulation of the dopamine system in diet-induced obesity. J Neurochem 120:891-898. CrossRef Medline

Waterland RA, Jirtle RL (2003) Transposable elements: targets for early nutritional effects on epigenetic gene regulation. Mol Cell Biol 23:52935300. CrossRef Medline

Wiench M, John S, Baek S, Johnson TA, Sung MH, Escobar T, Simmons CA, Pearce KH, Biddie SC, Sabo PJ, Thurman RE, Stamatoyannopoulos JA, Hager GL (2011) DNA methylation status predicts cell type-specific enhancer activity. EMBO J 30:3028 -3039. CrossRef Medline

Wu H, Coskun V, Tao J, Xie W, Ge W, Yoshikawa K, Li E, Zhang Y, Sun YE (2010) Dnmt3a-dependent nonpromoter DNA methylation facilitates transcription of neurogenic genes. Science 329:444-448. CrossRef Medline

Xu Y, Jones JE, Kohno D, Williams KW, Lee CE, Choi MJ, Anderson JG, Heisler LK, Zigman JM, Lowell BB, Elmquist JK (2008) 5-HT2CRs expressed by pro-opiomelanocortin neurons regulate energy homeostasis. Neuron 60:582-589. CrossRef Medline

Yeo GS, Heisler LK (2012) Unraveling the brain regulation of appetite: lessons from genetics. Nat Neurosci 15:1343-1349. CrossRef Medline

Yeo GS, Farooqi IS, Aminian S, Halsall DJ, Stanhope RG, O'Rahilly S (1998) A frameshift mutation in MC4R associated with dominantly inherited human obesity. Nat Genet 20:111-112. CrossRef Medline

Yura S, Itoh H, Sagawa N, Yamamoto H, Masuzaki H, Nakao K, Kawamura M, Takemura M, Kakui K, Ogawa Y, Fujii S (2005) Role of premature leptin surge in obesity resulting from intrauterine undernutrition. Cell Metab 1:371-378. CrossRef Medline

Zhou QY, Palmiter RD (1995) Dopamine-deficient mice are severely hypoactive, adipsic, and aphagic. Cell 83:1197-1209. CrossRef Medline 